Jurnal Media Pertanian Vol. 1 No. 1 Tahun 2016 Hal. 18 - 28

Media Komunikasi Hasil Penelitian dan Review Literatur Bidang Ilmu Agronomi

ISSN $2503-1279$

\title{
SERANGGA dan PERANANNYA \\ DALAM BIDANG PERTANIAN dan KEHIDUPAN
}

\author{
$\operatorname{Araz~Meilin~}^{1^{*}}$ dan Nasamsir ${ }^{1}$ \\ ${ }^{1}$ Program Studi Agroteknologi, Fakultas Pertanian Universitas Batanghari \\ Jl. Slamet Riyadi-Broni, Jambi, 36122 Telp. +62074160103 \\ *email korespondensi ; araz_meilin@yahoo.com \\ email ; nasamsirsamsir@yahoo.co.id
}

\begin{abstract}
The insect is a group of living thing that have the largest number of species. This article was compiled by aiming literature method studies at informing the negative and positive roles of insects in a farming and life. Some insects have a positive or negative role in agriculture and life. The negative role of insects in agriculture and life as cultivation plant, as a disease vector on the plant, and it cause humand being stickness. The positive role of insect is as pollinators, as a decomposer, as predators or parasitoids, as environment bioindikator, as the producer of the useful materials and beneficial in the field of health.
\end{abstract}

Keywords: insects, vectors, natural enemies, pollinators, decomposer

\begin{abstract}
Abstrak
Serangga merupakan kelompok makhluk hidup yang memiliki jumlah spesies terbanyak. Tulisan ini disusun dari studi literatur dan bertujuan menginformasikan peran negatif dan positif serangga dalam bidang pertanian dan kehidupan. Beberapa anggota dari serangga memiliki peranan positif maupun negatif di bidang pertanian dan kehidupan. Peran negatif serangga dibidang pertanian dan kehidupan adalah sebagai pemakan tumbuhan budidaya, sebagai vektor penyebab penyakit pada tanaman, dan sebagai penyebab penyakit pada manusia. Peran positif serangga adalah sebagai polinator atau penyerbuk, sebagai dekomposer atau pengurai, sebagai predator atau parasitoid (musuh alami), sebagai bioindikator lingkungan, sebagai penghasil bahan-bahan berguna dan bermanfaat dalam bidang kesehatan.
\end{abstract}

Kata Kunci: serangga, vektor, musuh alami, polinator, dekomposer

\section{PENDAHULUAN}

Serangga merupakan kelompok hewan yang dominan di muka bumi dengan jumlah spesies hampir 80 persen dari jumlah total hewan di bumi. Dari 751.000 spesies golongan serangga, sekitar 250.000 spesies terdapat di Indonesia. Serangga di bidang pertanian banyak dikenal sebagai hama (Kalshoven 1981). Sebagian bersifat sebagai predator, parasitoid, atau musuh alami (Christian dan Gotisberger 2000). Kebanyakan spesies serangga bermanfaat bagi manusia. Sebanyak 1.413.000 spesies telah berhasil diidentifikasi dan dikenal, lebih dari 7.000 spesies baru ditemukan hampir setiap tahun. Karena alasan ini membuat serangga berhasil dalam mempertahankan keberlangsungan hidupnya pada habitat yang bervariasi, kapasitas reproduksi yang tinggi, kemampuan memakan jenis makanan yang berbeda, dan kemampuan menyelamatkan diri dari musuhnya (Borror 1998).

Serangga dan laba-laba memiliki peranan penting didalam kehidupan manusia, terutama dibidang pertanian. Manusia selalu lebih sering melihat serangga secara antroposentris yaitu sebagai kelompok organisme yang lebih banyak mendatangkan 
Jurnal Media Pertanian Vol. 1 No. 1 Tahun 2016 Hal. 18 - 28

Media Komunikasi Hasil Penelitian dan Review Literatur Bidang Ilmu Agronomi

ISSN $2503-1279$

kerugian dari pada keuntungan bagi kehidupan manusia. Namun pada hakekatnya aspek-aspek positif dan manfaat serangga bagi kehidupan manusia jauh lebih besar dari pada aspek-aspek yang merugikan (Untung dan Sudomo, 1997).

Tulisan ini bertujuan memberikan informasi tentang peran negatif dan positif serangga dibidang pertanian dan kehidupan. Tulisan ini disusun dari beberapa literatur yang berhubungan dengan pokok bahasan.

\section{Peran Negatif Serangga Dibidang Pertanian dan Kehidupan}

Serangga mempunyai peranan penting dalam kehidupan manusia. Bila mendengar nama serangga, maka selalu diidentikkan dengan hama di bidang pertanian yang bersifat merugikan, seperti walang sangit, wereng, ulat grayak dan lainnya. Serangga dapat merusak tanaman sebagai hama dan sumber vector penyakit pada manusia. Ratusan butir telur kupu-kupu yang menempel pada daun, akan menetas menjadi ulat yang rakus mengunyah daun tanaman. Tanaman bukannya untung tapi malah rugi.

Serangga merugikan (Harmful or injerious insect) terdiri dari :

- Poisonous insect seperti ulat bajra atau ulat api, lebah

- Pest yaitu crop pest seperti serangga hama pada tanaman yang dibudidayakan, Plnat pest seperti serangga hama pada tanaman hutan atau tanaman sayuran lainnya.

- Stored groin pest seperti serangga hama gudang

- House hold pest seperti serangga hama pada rumah tangga, contohnya serangga kecoa

- Domestic animal pest seperti serangga hama pada luka yang diderita hewan ternak.

- Disease pests seperti serangga yang menyebabkan berbagai penyakit ataupun vektor penyakit.

Serangga dianggap sebagai hama ketika keberadaannya merugikan kesejahteraan manusia, estetika suatu produk, atau kehilangan hasil panen. Apabila pengertian hama itu hewan yang merugikan, maka serangga hama didefinisikan sebagai serangga yang mengganggu dan atau merusak tanaman haik secara ekonomis atuu estetis. Definisi hama itu tidak harus dihubungkan dengan pengendaliannya. Pada populasi serangga yang rendah sehingga kerugian yang diderita tanaman kecil, tetap serangga itu dikatakan serangga hama tetapi bukan memerlukan strategi pengendalian.

Jadi, permasalahan serangga di bidang pertanian tidak terlepas dari peran serangga sebagai hama. Serangga merupakan salah satu kelompok binatang yang merupakan hama utama bagi banyak jenis tanaman yang dibudidayakan manusia. Selain sebagai hama tanaman beberapa kelompok dan jenis serangga dapat menjadi pembawa atau vektor penyakit tanaman yang berupa virus atau jamur (Untung dan Sudomo, 1997). Serangga memiliki peran negatif disebabkan memakan tumbuhan (fitopag), sebagai vektor penyakit virus pada tanaman dan sebagai sumber penyakit pada manusia.

\section{Serangga sebagai fitofag atau pemakan tumbuhan}

Jumlah spesiesnya hanya $26 \%$ dari seluruh spesies serangga yang ada. Meskipun demikian, kalau tidak waspada serangga ini dapat menyebabkan kerugian yang tidak kecil pada usaha tani kita. Namun serangga-serangga fitofag yang hidup dengan memakan gulma dapat bermanfaat dalam pengendalian gulma secara hayati. Sebagai pemakan tumbuhan, serangga-serangga fitofag dapat memakan berbagai macam bagian tanaman mulai dari akar, batang, daun, bunga dan buah. Kebun jagung dihabiskan oleh 
Jurnal Media Pertanian Vol. 1 No. 1 Tahun 2016 Hal. 18 - 28

Media Komunikasi Hasil Penelitian dan Review Literatur Bidang Ilmu Agronomi

ISSN $2503-1279$

belalang atau ulat grayak, tanaman padi sawah hancur karena serangga wereng atau penggerek batang. Cara hidup serangga ini beragam, ada yang hidup di permukaan tanaman, dan ada juga yang hidup di dalam jaringan tanaman dengan cara mengorok, mengorek atau membentuk puru. Selain itu juga ada yang hidup di dalam tanah seperti perakaran. Diantara serangga fitofag, ada yang hidup hanya pada satu jenis tanaman, pada beberapa jenis tanaman namun masih dalam satu amili dan ada pula yang hidup pada beberapa jenis tanaman dari berbagai family. Serangga yang mempunyai satu inang disebut serangga manofag. Serangga yang mempunyai beberapa inang dalam satu family disebut serangga oligofag atau stenofag. Serangga yang mempunyai banyak inang dari banyak family tanaman disebut serangga polifag.

\section{Serangga sebagai vektor penyakit virus pada tanaman}

Beberapa tanaman (padi, tomat, cabai, ketimun, tembakau, lada, kacangkacangan, pisang, dll) dapat terserang penyakit yang disebabkan oleh virus melalui vektor serangga. Virus terbawa oleh serangga ini pada waktu mengisap pada tanaman sakit dan dan serangga ini berpindah dan mengisap pada tanaman sehat, virus tersebut tertular ke tanaman sehat.

Virus yang dapat menyebabkan penyakit adalah virus mosaik ketimun (Cucumber Mosaic Virus/CMV) Memiliki inang yang luas termasuk gulma. Jarang menyerang tanaman yang masih muda dan ditularkan oleh kutu daun. chili vein mottle virus (ChiVMV) ditularkan oleh kutu daun dan Jika populasi kutu daun sangat tinggi akan membentuk sayap sehingga mudah diterbangkan oleh angin, Potato Virus Y (PVY) menyerang tanaman cabe, kentang, tomat, dan tembakau. PVY ditularkan oleh kutu daun dan bahan biakan vegetatif. Tomato Spotted Wilt Ringspot Virus (Virus Bercak Bercincin) menyerang banyak tanaman inang dan ditularkan oleh Thrips. Gemini Virus (Virus Kuning) dapat menyerang tanaman cabai, tomat, tembakau, gulmayang ditularkan oleh kutu kebul (Bemisia tabaci). Jumlah kutu yang sedikit sudah cukup untuk menyebarkan karena serangga dewasa aktif bergerak.

Kutu putih Ferrisia virgata dan Planococcus telah diketahui peranannya sebagai serangga vektor penyakit kerdil pada tanaman lada baik di Indonesia maupun di negara Asia Tenggara lainnya. Kedua serangga tersebut berperan sebagai serangga vektor PYMV pada tanaman lada, sedangkan A. gossypii berperan dalam menularkan CMV (Eng, 2000). Kutu putih ini dikenal sebagai vektor yang efisien, artinya serangga tersebut mempunyai kemampuan menularkan yang cukup tinggi. Berdasarkan hasil penularan sebanyak dari 5 serangga ekor per tanaman (yang telah diberi makan pada tanaman sakit) mampu menghasilkan gejala sebesar 35\% (Balfas dan Mustika, 2004; Balfas et al., 2003).

Penyakit tungro disebabkan oleh dua jenis virus yang berbeda yaitu virus bentuk batang Rice Tungro Bacilliform Virus (RTBV) dan virus bentuk bulat Rice Tungro Spherical Virus (RTSV). Kedua jenis virus tersebut tidak memiliki kekerabatan serologi dan dapat menginfeksi tanaman secara bersama-sama. Virus tungro hanya ditularkan oleh wereng hijau (sebagai vektor) tidak terjadi multiplikasi dalam tubuh wereng dan tidak terbawa pada keturunananya. Sejumlah species wereng hijau dapat menularkan virus tungro, namun Nephotettix virescens merupakan wereng hijau yang paling efisien sehingga perlu diwaspadai keberadaannya. Penularan virus tungro dapat terjadi apabila vektor memperoleh virus setelah mengisap tanaman yang terinfeksi virus kemudian berpindah dan mengisap tanaman sehat tanpa melalui periode laten dalam tubuh vektor. 
Jurnal Media Pertanian Vol. 1 No. 1 Tahun 2016 Hal. 18 - 28

Media Komunikasi Hasil Penelitian dan Review Literatur Bidang Ilmu Agronomi

ISSN $2503-1279$

Di Pulau Jawa, Sumatera, dan Sulawesi Orosius argentatus (Hemiptera: Ciccadellidae) menjadi vektor penyakit sapu pada beberapa tanaman kacang-kacangan, termasuk pada tanaman kacang tanah. Penyakit sapu yang disebabkan oleh fitoplasma dapat menyebabkan kehilangan hasil yang nyata pada kacang tanah (Arachis hypogaea ). Penularan fitoplasma yang paling utama di lapangan ialah melalui serangga vektor. Orosius argentatus dapat menularkan virus fitoplasma penyebab penyakit sapu pada kacang tanah (Sastrini dan Mutaqin, 2013). Spesies lain dari famili Ciccadellidae ialah Empoasca sp. yang dilaporkan menjadi vektor fitoplasma penyebab penyakit sapu pada kacang gude (Cajanus cajan) di Florida (McCoy et al. 1983),

Penyakit darah pisang disebabkan oleh blood disease bacterium (BDB) diduga dapat ditularkan oleh serangga Ordo Diptera, Famili Drosophilidae. Serangga Drosophilidae mampu menularkan patogen ke tanaman Heliconia yang sehat (Sahetapy, 2013).

\section{Serangga sebagai sumber penyakit pada manusia}

Serangga mampu menyebarkan penyakit dan kematian. Penyakit yang ditularkan serangga "bertanggung jawab atas lebih banyak penyakit dan kematian manusia pada abad ke-17 hingga awal abad ke-20 dari pada gabungan semua penyebab lainnya", kata Duane Gubler dari Pusat Pengendalian dan Pencegahan Penyakit AS. Sekarang ini, kira-kira 1 dari setiap 6 orang terinfeksi penyakit yang diperoleh melalui serangga. Selain menyebabkan penderitaan manusia, penyakit yang ditularkan serangga mengakibatkan beban keuangan yang berat, khususnya bagi negara-negara berkembang - yang paling tidak mampu menanggung biayanya. Bahkan sebuah wabah saja dapat menelan biaya yang besar. Sebuah insiden semacam itu di India bagian barat pada tahun 1994 konon telah menguras miliaran dolar dari perekonomian setempat dan dunia. Menurut Organisasi Kesehatan Dunia (WHO), negara-negara termiskin di dunia tidak akan sanggup maju secara ekonomi sampai problem kesehatan semacam itu dikendalikan (Sedarlah, 2003).

Ada dua cara utama bagaimana serangga berfungsi sebagai vektor-penular penyakit. Yang pertama adalah dengan penularan mekanis. Sebagaimana manusia dapat membawa tanah ke dalam rumah lewat sepatu yang kotor, "lalat rumah bisa membawa jutaan mikroorganisme pada kaki mereka yang, dalam dosis yang cukup besar, dapat menyebabkan penyakit", kata Encyclopæedia Britannica. Misalnya, lalat dapat membawa zat pencemar dari tinja dan meneruskannya ketika mereka hinggap di atas makanan atau minuman kita. Dengan cara inilah manusia tertular penyakit yang melemahkan dan mematikan seperti tifoid, disentri, dan bahkan kolera. Lalat juga turut menyebarkan trakoma - penyebab utama kebutaan di dunia ini. Trakoma dapat membutakan orang dengan melukai kornea — bagian bening dari mata di depan iris. Di seluas dunia, sekitar 500.000.000 orang menderita bala ini. Kecoak, yang tumbuh pesat di kotoran, juga diduga menularkan penyakit secara mekanis. Selain itu, para pakar mengaitkan peningkatan tajam penyakit asma belum lama ini, khususnya di kalangan anak-anak, dengan alergi terhadap kecoa (Sedarlah, 2003).

Apabila serangga menyimpan virus, bakteri, atau parasit dalam tubuh mereka, mereka dapat menyebarkan penyakit dengan cara kedua - dengan meneruskannya melalui gigitan atau cara lain. Hanya sebagian kecil serangga yang menularkan penyakit kepada manusia dengan cara ini. Sebagai contoh, meskipun ada ribuan spesies nyamuk, hanya genus Anopheles yang menularkan malaria-penyakit menular paling mematikan nomor dua di dunia (setelah tuberkulosis). Namun, nyamuk lain menularkan banyak 
Jurnal Media Pertanian Vol. 1 No. 1 Tahun 2016 Hal. 18 - 28

Media Komunikasi Hasil Penelitian dan Review Literatur Bidang Ilmu Agronomi

ISSN $2503-1279$

penyakit yang berbeda. WHO melaporkan, "Dari semua penyakit yang ditularkan serangga, nyamuk adalah ancaman yang terbesar, menyebarkan malaria, demam berdarah, dan demam kuning, yang semuanya bertanggung jawab atas beberapa juta kematian dan ratusan juta kasus [penyakit menular] setiap tahun." Sekurang-kurangnya $40 \%$ penduduk dunia berisiko tertular malaria, dan sekitar $40 \%$ berisiko tertular demam berdarah. Di banyak tempat, seseorang dapat tertular kedua-duanya. Tentu saja, nyamuk bukan satu-satunya serangga yang membawa penyakit dalam tubuh mereka. Lalat tsetse menularkan protozoa penyebab penyakit tidur, menjangkiti ratusan ribu orang dan memaksa segenap komunitas menelantarkan ladang mereka yang subur. Dengan menularkan organisme yang menyebabkan kebutaan sungai, lalat hitam telah merampas penglihatan sekitar 400.000 orang Afrika. Lalat pasir dapat membawa protozoa yang menyebabkan leismaniasis, sekelompok penyakit yang melumpuhkan, merusak, dan sering kali berakibat fatal yang sekarang ini menjangkiti jutaan orang dalam segala usia di seputar dunia. Kutu yang ada di mana-mana dapat menjadi inang cacing pita, ensefalitis, tularemia, dan bahkan pes-pada umumnya berkaitan dengan Sampar Hitam, yang dalam enam tahun saja menewaskan sepertiga atau lebih penduduk Eropa selama Abad Pertengahan (Sedarlah, 2003).

Kutu pengisap, tungau, dan caplak dapat menularkan berbagai macam penyakit tifus, selain penyakit lainnya. Caplak di negeri-negeri beriklim sedang di seputar dunia dapat membawa penyakit Lyme yang berpotensi melemahkan-penyakit yang ditularkan vektor yang paling umum di Amerika Serikat dan Eropa. Sebuah penelitian di Swedia menyingkapkan bahwa burung-burung yang bermigrasi dapat membawa caplak sejauh ribuan kilometer, mungkin memasukkan penyakit yang mereka bawa ke kawasan baru. "Caplak," kata Britannica, "mengungguli semua artropoda lainnya (kecuali nyamuk) dalam jumlah penyakit yang mereka tularkan kepada manusia." Sebenarnya, seekor caplak saja dapat membawa sampai tiga organisme penyebab penyakit yang berbeda dan dapat menularkan semuanya dengan satu gigitan saja! (Sedarlah, 2003).

\section{Peran Positif Serangga di Bidang Pertanian dan Kehidupan}

Tidak semua serangga bersifat merugikan karena juga ada serangga yang memiliki dampak positif. Sebagian serangga bersifat sebagai predator, parasitoid, atau musuh alami (Christian dan Gotisberger 2000). Melalui peran sebagai musuh alami, serangga sangat membantu manusia dalam usaha pengendalian hama. Selain itu serangga juga membantu dalam menjaga kestabilan jaring-jaring makanan dalam suatu ekosistem pertanian. Serangga juga diperlukan untuk kehidupan manusia. Serangga dari kelompok lebah, belalang, jangkrik, ulat sutera, kumbang, semut membantu manusia dalam proses penyerbukan tanaman dan menghasilkan produk makanan kesehatan. Peranan serangga dalam ekosistem antara lain sbagai pollinator, dekomposer, predator (pengendali hayati), parasitoid hingga sebagai bioindikator bagi suatu ekosistem sehingga dengan adanya kegunaan serangga itu akan sangat bepengaruh dalam bidang pertanian. Kelompok serangga yang peranannya berguna disebut juga Helful or beneficial insect. Peranan positif serangga adalah sebagai berikut:

\section{Serangga sebagai pollinator contohnya adalah lebah dan kupu-kupu}

Lebah juga bukan merupakan satu-satunya serangga yang bertugas memperlancar penyerbukan bunga. Namun ia merupakan satu-satunya serangga yang saat melakukan polinasi tidak menimbulkan efek samping yang merugikan bagi tanaman. Berbeda dengan kupu-kupu, misalnya tak ada yang menyangkal bahwa kupu- 
Jurnal Media Pertanian Vol. 1 No. 1 Tahun 2016 Hal. 18 - 28

Media Komunikasi Hasil Penelitian dan Review Literatur Bidang Ilmu Agronomi

ISSN $2503-1279$

kupu yang mengisap madu itu mampu membantu menempelkan serbuk sari pada kepala putik sebuah bunga, dan itu akan mempermudah proses pembentukan buah. Lebah sendiri merupakan pollinator tanaman yang paling penting di alam dibandingkan angin, air dan serangga lainnya. Banyak peneliti mengungkapkan bahwa terdapat kenaikan produksi jika sejumlah koloni lebah diletakkan di sekitar lokasi tanaman. Lebah memiliki organ khusus untuk mengambil nektar, yang disebut proboscis yang bentuknya seperti belalai pada gajah. Proboscis memiliki kemampuan mengisap cairan nectar pada bunga. Aktivitas terbang lebah mengumpulkan nektar dan polen berlangsung sejak pagi sampai sore hari. Polen diperlukan oleh lebah madu terutama sebagai sumber protein dan lemak, dan sedikit karbohidrat dan mineral. Aktivitas lebah tersebut dilakukan secara tidak sengaja pada saat pencarian nectar dan tepung sari sebagai bahan pakan untuk koloninya. Menurut Freitas dan Paxton, (1996), tanaman yang mendapat bantuan penyerbuk dalam proses pembuahan, menghasilkan hasil panen yang lebih banyak. Oleh sebab itu, agar hasil produksi meningkat harus diperhatikan pengelolaan serangga penyerbuk agar populasinya cukup ketika musim pembungaan. Selain itu strain tanaman dipilih yang dapat menghasilkan polen yang cocok satu sama lain. Penggunaan pestisida yang tidak tepat juga dapat membunuh penyerbuk.

\section{Serangga sebagai dekomposer atau pengurai}

Serangga-serangga tersebut akan memakan tanaman-tanaman yang sudah tua sehingga mengembalikan unsur hara dalam tanah dan membuat tanah menjadi subur. Contoh serangga sebagai dekomposer adalah rayap. Dapat diinformasikan bahwa kehadiran rayap sejak awal mula adalah sebagai organism pemakan kayu (bahan organik), namun, karena perubahan kondisi habitat akibat aktivitas manusia sehingga rayap menjadi serangga hama yang merugikan. Rayap merupakan hama pada tanaman karet yang menyerang akar dan batang tanaman sehinga mengakibatkan pelukaan dan jaringan mengalami kerusakan. Rayap meskipun banyak mengganggu atau menjadi hama bagi tanaman tetapi juga brguna bagi keseimbangan tanah.

\section{Serangga sebagai parasitoid dan predator}

Kelompok serangga ini hidup dengan cara memakan serangga lain baik sebagian maupun seluruhnya. Perbedaan antara predator dan parasitoid terletak pada cara hidup dan cara makan serangga lain tersebut. Predator umumnya aktif dan mempunyai tubuh yang lebih besar dan lebih kuat dari serangga mangsanya, walaupun ada predator yang bersikap menunggu seperti belalang sembah. Istilah parasitoid digunakan untuk membedakannya dalam istilah parasit sungguhan seperti umum dijumpai pada hewan vetebrata. Predator dan parasitoid berperan penting sebagai agen pengendali alami di dalam ekosistem, pada ekositem buatan umumnya kehidupan kelompok serangga ini sering terganggu oleh campur tangan manusia dalam kegiatan budi daya tanaman, terutama dalam penggunaan pestisida. Semut ada yang bersifat sebagai predator maupun pemakan bahan organik tanah. Semut-semut yang berasosiasi dengan serangga penghasil embun madu seperti aphid, Stictococcus sp., Planococcoides njalensis dan T. aurantii adalah Pheidole megacephala, Crematogaster africana Mayr, Crematogaster striatula Emery, Oecophylla longinoda Latr., Cataulacus guineensis Smith, Polyrachis laboriosa Smith, dan Camponotus olivieri F. (Dwomoh, Ackonor dan Afun., 2008).

\section{Serangga sebagai bioindikator lingkungan}

Serangga bioindikator merupakan hewan yang sangat sensitif/responsif terhadap perubahan atau tekanan pada suatu ekosisitem dimana ia hidup. Penggunaan serangga sebagai bioindikator kondisi lingkungan atau eksosisitem yang ditempatinya telah lama 
Jurnal Media Pertanian Vol. 1 No. 1 Tahun 2016 Hal. 18 - 28

Media Komunikasi Hasil Penelitian dan Review Literatur Bidang Ilmu Agronomi

ISSN $2503-1279$

dilakukan. Jenis serangga ini mulai banyak diteliti karena bermanfaat untuk mengetahui kondisi kesehatan suatu ekosistem. Serangga akuatik selama ini paling banyak digunakan untuk mengetahui kondisi pencemaran air pada suatu daerah, diantaranya adalah beberapa spesies serangga dari ordo Ephemeroptera, Diptera, Trichoptera dan Plecoptera yang kelimpahan atau kehadirannya mengindikasikan bahwa lingkungan tersebut telah tercemar, karena serangga ini tidak dapat hidup pada habitat yang sudah tercemar. Adapun untuk serangga daratan ('terrestrial insect') studi sejenis telah banyak dilakukan pada berbagai kawasan hutan di berbagai negera termasuk di kawasan hutantropis (Shahabuddin, 2003). Ditambahkan oleh Wardhani (2007) dalam laporannya bahwa, larva Odonata juga berpotensi sebagai bioindikator pencemaran air, karena larva ini sangat sensitif terhadap perubahan kualitas air. Bila kualitas air sungai sebagai habitatnya tercemar, maka larva odonata akan mati

\section{Serangga penghasil bahan-bahan yang berguna bagi manusia}

Di antara kelompok serangga penghasil bahan-bahan yang berguna, yang paling menonjol adalah lebah madu. Serangga ini selain menghasilkan madu juga sebagai serangga penyerbuk. Selain lebah madu contoh serangga lain adalah ulat sutera (Bombyx mori) dan serangga penghasil Lak yaitu Laccifer lacca. Belalang merupakan serangga yang selama ini dianggap sebagai hama dan merugikan. Makan belalang pun identik dengan kemiskinan, padahal kandungan protein belalang menurut penelitian Kusmaryanti (2005) jauh lebih tinggi daripada tepung udang. Tepung belalang kayu (Melanoplus cinereus) mempunyai nilai protein yang lebih tinggi dari udang windu (Panaeneous Monodon). Kadar protein tepung belalang kayu sebesar 17,922\% sedangkan tepung udang windu hanya $9,846 \%$. Protein mempunyai peranan yang sangat penting dalam kelangsungan hidup manusia. Kekurangan protein dalam waktu lama dapat mengganggu berbagai proses dalam tubuh dan menurunkan daya tahan tubuh terhadap berbagai penyakit. Sebagian besar warga di Gunungkidul telah mengenal dan mengkonsumsi belalang sebagai lauk-pauk makan sehari-hari. Walaupun semula belalang identik dengan lauk-pauk orang miskin, namun makan belalang adalah suatu kenangan yang tak terlupakan bagi warga yang telah lama merantau keluar dari Gunung kidul. Sehingga belalang merupakan makanan yang selalu dicari dan tetap lestari di daerah Gunung kidul. Selama ini belalang hanya dimanfaatkan sebagai makanan khas yang cara mengkonumsinya hanya dengan digoreng, dan belum dimanfaatkan menjadi produk pangan lokal yang bernilai ekonomi lebih tinggi. Berbagai produk olahan pangan dari bahan baku belalang yang lebih bervariasi selain kerupuk, yaitu lemper, opak, pangsit, abon dan sebagainya. Menurut Asthami, Estiasih dan Maligan., (2016), tepung belalang kayu dapat ditambahkan dalam formulasi mie instan karena produk mie instan belalang yang dihasilkan memiliki nilai kuantitas dan kualitas protein yang lebih tinggi dibandingkan dengan mie instan komersial yang berada dipasaran.

Belalang dan jangkrik adalah jenis serangga yang paling umum dikonsumsi di seluruh dunia. Serangga yang jago melompat ini memang mudah ditemukan, mudah ditangkap, dan rasanya lezat. Dalam 3-5 ons belalang mentah terkandung 14-28 gram protein. Belalang juga kaya kalsium dan zat besi. Kelebihan lain dari belalang adalah rasanya yang netral sehingga bisa dibuat menjadi berbagai panganan. Cara paling populer untuk mengasup belalang adalah digoreng atau dipanggang. Belalang dan jangkrik digemari penduduk Indonesia di kawasan timur. Mereka memenggang atau menyangrainya, rasanya lembut dan segurih udang. 
Jurnal Media Pertanian Vol. 1 No. 1 Tahun 2016 Hal. 18 - 28

Media Komunikasi Hasil Penelitian dan Review Literatur Bidang Ilmu Agronomi

ISSN $2503-1279$

Ulat juga sering dikonsumsi. Dalam 100 gram ulat yang dikeringkan terkandung 53 gram protein dan 15 persen lemak. Kandungan protein dalam ulat bahkan lebih tinggi dibanding ikan dan daging. Kumbang mengandung 36 gram protein dalam satu sajian kecil. Selain itu hewan ini juga mengandung mineral seperti kalsium, zat besi, dan zinc. Jangkrik dan semut juga dijadikan sumber makanan protein hewani, selain sebagai pakan burung, ikan hias, udang, umpan pancing, dan banyak spesies lainnya yang berguna bagi kehidupan.

Penduduk pada beberapa kawasan di Indonesia (seperti Irian) mengkonsumsi belalang sebagai sumber lauk sehari-hari, namun tidak populer di kawasan lainnya. Maka perlu dimasyarakatkan cara mengolah dan memasaknya untuk mendapatkan cita rasa yang nikmat. Dari sudut pandangan agama, mengkonsumsi serangga bukan hal yang diharamkan. Prospek pemanfaatn serangga terbuka luas. Ulat sagu sangat digemari oleh masyarakat Ambon karena rasanya manis, lunak dan lezat.

Penggemar lebah madu/tawon mengambil madu, lilin tawon, susu madu, perekat lebah bernilai ekonomis, dan larvanya dengan cara berburu di alam.

\section{Serangga bermanfaat dalam bidang kesehatan.}

Telur Belalang berkhasiat untuk mengobati jerawat. Belalang bersifat panas dan kering, konsumsi dalam jumlah banyak dapat melangsingkan tubuh. Belalang juga mempunyai khasiat untuk mengobati berbagai penyakit, seperti sakit kuning, sesak nafas karena batuk, setip/kejang dan infeksi sumsum tulang. Untuk mengobati sakit kuning, dilakukan dengan menghirup asap pembakaran sepuluh ekor belalang. Sesak nafas karena batuk dapat diobati dengan mengkonsumsi ramuan tepung belalang (5 ekor) yangg dicampur dengan 1 sendok makan arak manis, setiap pagi dan sore (Haryanto, 2005).

\section{Strategi pengelolaan ekosistem pertanian berdasarkan peranan serangga}

Dengan mempelajari struktur ekosistem seperti komposisi jenis-jenis tanaman, hama, musuh alami, dan kelompok biotik lainya, serta interaksi dinamis antar komponen biotik, dapat ditetapkan strategi pengelolaan yang mampu mempertahankan populasi hama pada suatu aras yang tidak merugikan. Agroekosistem perlu dikelola sedemikian rupa sehingga musuh alami dapat dilestarikan dan dimanfaatkan. Setiap jenis hama secara alami dikendalikan oleh kompleks musuh alami yang dapat meliputi predator (pemangsa), parasitoid, dan patogen hama. Dibandingkan dengan penggunaan pestisida, penggunaan musuh alami bersifat alami, efektif, murah, dan tidak menimbulkan dampak samping negatif bagi kesehatan dan lingkungan hidup (Untung, 2006). Pengelolaan serangga pada jambu mete diarahkan terhadap pemanfaatan sumberdaya alam yang ada dengan mengutamakan kehadiran serangga berguna (Soesanthy dan Trisawa, 2011).

Dalam pengelolaan serangga yang berorientasi pada bekerjanya sistem alami, maka perlu dihindari faktor-faktor yang dapat mengganggu sistem tersebut seperti pembakaran sisa pemangkasan dan atau vegetasi liar, serta penggunaan insektisida sintetik. Menurut Supriadi et al. (2002) praktek pembakaran dapat membunuh seranggaserangga berguna yang hidup dan berkembang biak di atas permukaan tanah. Penggunaan insektisida dapat berpangaruh buruk terhadap musuh alami. Oleh karena itu, penggunaannya dilakukan sebagai alternatif terakhir jika cara pengelolaan sebelumnya kurang berhasil dalam menekan populasi serangga yang merugikan, Penggunaannya harus dilakukan secara bijaksana misalnya dengan memperhatikan saat yang tepat untuk aplikasi (Soesanthy dan Trisawa, 2011). 
Jurnal Media Pertanian Vol. 1 No. 1 Tahun 2016 Hal. 18 - 28

Media Komunikasi Hasil Penelitian dan Review Literatur Bidang Ilmu Agronomi

ISSN $2503-1279$

Pengendalian penyakit yang disebabkan oleh virus sangat sulit. Oleh karena itu yang dapat dilakukan adalah melakukan tindakan pencegahan. Untuk menghindari penyebaran penyakit menghendaki keberhasilan penunggalan serangga vektor yang amat tinggi sejak pembibitan sampai di lapang. Persemaian harus bebas dari kutu putih dan aphid dan apabila telah terlihat ada tanaman yang terserang penyakit kerdil di lapang, maka perlu dilakukan pengendalian serangga vektor (Eng, 2002). Disamping itu penyebaran penyakit dapat dicegah apabila dilakukan penyemprotan secara teratur dan secara bersama-sama dan hamparan yang cukup luas. Karena apabila penanggulangan hanya pada satu atau dua kebun saja, sementara tanaman lain disekelilingnya tidak, maka masih memungkinkan untuk terjadinya penularan. Sampai saat ini belum diketahui adanya tanaman yang resisten atau toleran terhadap serangan kutu putih. Pengendalian secara biologis kurang memungkinkan karena untuk pengendalian serangga vektor menghendaki penekanan serangga vektor yang cukup tinggi.

Insektisida sintetik dapat digunakan untuk mengendalikan serangga vektor kutu putih terutama Planococcus dan akan lebih baik menggunakan insektisida sintetik yang sistemik, karena serangga ini tersembunyi pada bagian tanaman sehingga tidak terkena dengan insektisida kontak. Hasil penelitian penanggulangan kutu putih pada tanaman lada di rumah kaca dengan ekstrak jarak, ekstrak mimba dan inksektisida sintetik selama tiga bulan menunjukkan ekstrak jarak cukup efektif menekan tumbuhnya kutu putih (Balfas dan Mustika, 2005).

\section{PENUTUP}

Serangga merupakan kelompok makhluk hidup yang memiliki jumlah spesies terbanyak. Beberapa anggota dari serangga memiliki peranan positif maupun negatif di bidang pertanian dan kehidupan. Peran negatif serangga dibidang pertanian dan kehidupan adalah sebagai pemakan tumbuhan budidaya, sebagai vektor penyebab penyakit pada tanaman, dan sebagai penyebab penyakit pada manusia. Peran positif serangga adalah sebagai polinator atau penyerbuk, sebagai dekomposer atau pengurai, sebagai predator atau parasitoid (musuh alami), sebagai bioindikator lingkungan, sebagai penghasil bahan-bahan berguna dan bermanfaat juga dalam bidang kesehatan.

\section{DAFTAR PUSTAKA}

Asthami N, T Estiasih, JM Maligan. 2016. Mie instan belalang kayu (Melanoplus cinereus): Kajian Pustaka. Jurnal Pangan dan Agroindustri 4 (1): .238-244.

Balfas, R. Supriadi dan Endang Sugandi, 2003. Penularan penyakit kerdil asal Bangka oleh Planococcus. Risalah Simposium Nasional Penelitian PHT Perkebunan Rakyat, Bogor 17 - 19 September 2002. Bagian Proyek PHT Tanaman Perkebunan. Hal. 207 - 212.

Balfas, R. dan I. Mustika, 2004. Penularan penyakit kerdil pada tanaman lada oleh Ferrisia virgata. Makalah disampaikan pada Seminar PERSADA. Bogor, 5 Juli 2004. 
Jurnal Media Pertanian Vol. 1 No. 1 Tahun 2016 Hal. 18 - 28

Media Komunikasi Hasil Penelitian dan Review Literatur Bidang Ilmu Agronomi ISSN $2503-1279$

Borror et al. 1998. Pengenalan Pelajaran Serangga. $8^{\text {th }}$ Ed. Terjemahan dari an Introduction to Study of Insect oleh Soetiyono Partosoedjono. Yogyakarta: Gajah Mada University Press.

Christian W, Gottsberger G. 2000. Diversity preys in Crop Pollination. Crop Science 40 (5): 1209-1222.

Dwomoh EA, Ackonor JB, Afun JVK. 2008. Survey of insect species associated with cashew (Anacardium occidentale Linn.) and their distribution in Ghana. African $J$ Agril Res 3(3):205-214

Eng, L., 2002. Viral disease and root-knot nematode problems of black pepper (Piper nigrum L.) in Sarawak, Malaysia. Symposiumon pests and diseases on pepper, 24th September 2002. Annex Ss-07. p. 1 - 8.

Freitas BM, Paxton RJ. 1996. The role of wind and insects in cashew (Anacardium occidentale) pollination in NE Brazil. J Agric Sci 126:319-326.

Haryanto S. 2005. 30 Jenis Hewan Penakluk Penyakit. Penebar Swadaya, Jakarta.

Kalshoven LGE. 1981. Pest of Crops in Indonesia. Van der Laan PA, penerjemah. Jakarta: Ichtiar Baru-Van Hoeve. (Terjemahan dari: De Plagen van de Cultuurgewassen in Indonesie).

Kusmaryani. 2005. dalam http://www.smallcrab.com/kesehatan/25-healthy/292protein-belalang-lebih-tinggi-dari-udang.

Shahabuddin, 2003. Pemanfaatan Serangga Sebagai Bioindikator Kesehatan Hutan. Pengantar Falsafah Sains (PPS702) Program Pascasarjana/S3 Institut Pertanian Bogor. Bogor.

Sahetapy, B. 2013. Peranan Beberapa Jenis Serangga sebagai Vektor Penyakit Darah Pada Tanaman Pisang. Disertasi. Sekolah Pascasarjana, Institut Pertanian Bogor. Bogor.

Sastrini T, KH Mutaqin. 2013. Penularan fitoplasma sapu pada tanaman kacang tanah oleh Serangga Vektor Orosius argentatus dan Deteksi Molekuler dengan Teknik PCR. Jurnal Fitopatologi Indonesia 9 (1) : 21-28.

Sedarlah. 2003. Penyakit yang Ditularkan Serangga-Problem yang Meningkat http://wol.jw.org/id/wol/d/r25/lp-in/102003361\#h=13

Soesanthy, F., IM. Trisawa. 2011. Pengelolaan Serangga-Serangga yang Berasosiasi dengan Tanaman Jambu Mete. Buletin RISTRI 2 (2) : 221-230.

Supriadi, Siswanto, Karmawati E, Rahayuningsih S, Sitepu D, Adhi EM, Wikardi EA, Wiratno, Wahyono TE, Sukmana C. 2002. Pengelolaan Ekosistem Jambu Mete 
Jurnal Media Pertanian Vol. 1 No. 1 Tahun 2016 Hal. 18 - 28

Media Komunikasi Hasil Penelitian dan Review Literatur Bidang Ilmu Agronomi ISSN $2503-1279$

Berdasarkan Teknologi PHT. Laporan Hasil Penelitian PHT Tahun 2001. Pusat Penelitian dan Pengembangan Perkebunan, Bogor. 50 hlm.

Untung, K. 2006. Pengantar Pengelolaan Hama Terpadu. Gadjah Mada University Press. Yogyakarta.

Untung, K., Sudomo, M. 1997. Pengelolaan Serangga Secara Berkelanjutan. Makalah disampaikan pada Simposium Entomologi. Bandung.

Wardhani, T.S., 2007. Perbandingan Populasi Larva Odonata di Beberapa Sungai di Pulau Pinang dan Hubungannya dengan Pengaruh Habitat dan Kualiti Air. Universiti Sains Malaysia. 